\title{
Magdalena Bednarek Ile pomieści mała forma? (O miniaturach wielkich form narracyjnych w powojennej prozie polskiej) ${ }^{*}$
}

\begin{abstract}
Bednarek Magdalena, Ile pomieści mała forma? (O miniaturach wielkich form narracyjnych w powojennej prozie polskiej) [How much can a short narrative hold? (About miniatures of large narrative genres in the postwar Polish prose)]. „Przestrzenie Teorii" 13. Poznań 2010, Adam Mickiewicz University Press, pp. 163-189. ISBN 978-83-232-2176-0. ISSN 1644-6763.

Short narratives as a highly represented group in the postwar Polish literature demands researches, especially when the only work concerning the subject 'Theoretical Problems of Small Literary Forms' by J. Trzynadlowski was written thirty years ago and therefore is selective and most of its conclusions are simply out-of-date. In this article 'short narrative' is used as a descriptive category used to embrace all the short literary pieces characterized by minimalisms of material (a concept by J. Barth). In this text appear references to the tradition of genres which I mean as a hermeneutic space following in this the postulates of architextuality, the theory created by G. Genette and popularized in Poland by S. Balbus, R. Nycz, P. Michałowski. Miniatures of large narrative genres - such as novel, diary, or epos - are unique among those. Icons and falsified indexes (which only pretend to be fragments of bigger forms) constitute ways of large genres' appearance in short narratives. Functions of these references are not restricted to ludic ones, but raise problems of metatextuality, the cultural origins and restrictions of genres and even carry some criticism of social life and economic issues in socialistic countries. All this is proved by interpretations of works by M. Białoszewski, B. Czałczyńska, M. Głowiński, S. Mrożek, T. Parnicki, A. Stern.
\end{abstract}

Układanie obszernych ksiażek to pracowite i zubożajace
szalenstwo: rozwijanie na pięciuset stronach idei,
której doskonaty ustny wyktad zajmuje kilka minut ${ }^{1}$.

Małe formy narracyjne, pomimo że liczne i różnorodne, w polskim literaturoznawstwie, nie stanowią niezależnej, uznanej kategorii; funkcjonują bardziej jako człon opozycji spopularyzowanej przez Henryka Markiewicza, na którą składają się wielkie i małe formy epickie². Jakkolwiek oba terminy są nieprecyzyjne, łatwiej scharakteryzować pierwszą grupę,

* Artykuł powstał w ramach grantu promotorskiego numer N N103 314136 Małe formy narracyjne $w$ przestrzeni genologicznej (Literatura polska 1945-1989). Termin realizacji: 2009-2010.

1 J.L. Borges, Prolog, [w:] Fikcje, przeł. A. Sobol-Jurczykowski, S. Zembrzuski, przypisy oprac. A. Sobol-Jurczykowski, Prószyński i S-ka, Warszawa 2003, s. 10.

2 Zob. H. Markiewicz, Rodzaje i gatunki literackie, [w:] Gtówne problemy wiedzy o literaturze, wyd. V przejrzane i uzupełnione, Wyd. Literackie, Kraków 1980. 
obejmującą m.in. powieść, epopeję, romans ( $\mathrm{w}$ ujęciu jakościowym to utwory wielowątkowe, w ilościowym - o znacznej objętości). Drugi biegun opozycji tworzą natomiast opowiadania oraz nowele, tutaj mieściłyby się także (jakże odmienne!) anegdoty, baśnie, obrazki, charaktery, fizjonomie itp. Na oznaczenie tej grupy tekstów używa się kilku bliskoznacznych określeń: krótkie formy epickie, małe formy narracyjne, małe formy prozatorskie $^{3}$. Ta niejednoznaczność terminologiczna wskazuje na niepewność epistemiczną samego zjawiska - pomimo że w praktyce twórczej niewielkie teksty prozatorskie są zjawiskiem częstym, ich istnienie jako kategorii teoretycznej pozostaje problematyczne ${ }^{4}$. Sytuację tę poświadcza stan badań nad małymi formami; choć liczne są tomy interpretacyjne, (koncentrujące się jednak na nowelistyce i opowiadaniach ${ }^{5}$ ), jedynym opracowaniem teoretycznym pozostaje książka Jana Trzynadlowskiego (1977).

3 Te bliskoznaczne określenia odmiennie jednak formują pole badawcze. Kategoria „małych form literackich” jest najogólniejsza i ogarnia zarówno anegdoty, dowcipy, facecje, żarty, jak i bajki czy fraszki. Jednocześnie węższe pojęcia „małych form epickich” czy „krótkich form narracyjnych” prowadzą do podobnych konsekwencji: także ignorują formę podawczą, obejmując teksty prozatorskie i wierszowane, wykluczając natomiast ukształtowanie dramatyczne i liryczne. Funkcjonując w opozycji do wielkich form epickich, odnoszą się przede wszystkim do opowiadania, noweli, powiastki filozoficznej, na uboczu pozostawiając facecję czy charakter. Nieco odmienną propozycję terminologiczną stanowią „mikroprozy”, „małe prozy” czy też „małe formy prozatorskie” stosowane przez krytyków (por. np. S. Balbus, Sztuka małej prozy, „Pismo” 1981, nr 4) oraz pisarzy (zob. M. Białoszewski, Małe i większe prozy, S. Mrożek, Małe prozy 1980-1989), które akcentują formę podawczą, równouprawniając epikę, dramat i lirykę. Jakkolwiek pojęcie to jest pojemne, uzus skłania do utożsamiania go z małymi formami epickimi; formy aktywizujące poziomy wypowiedzi niższe niż zdanie (odwołując się do rozróżnień poczynionych przez W. Boleckiego, zob. Poetycki model prozy $w$ dwudziestoleciu międzywojennym, Zakład Narodowy im. Ossolińskich, Wrocław 1982) nosiłyby wówczas miano prozy poetyckiej. W dużym stopniu ujęcie to odwołuje się także do potocznych klasyfikacji w obrębie tekstów literackich; w stosunku do konkurencyjnych propozycji jest z jednej strony szersze (o formy dialogiczne i liryczne), z drugiej natomiast węższe - o teksty wierszowane. Nie zmienia to jednak faktu, że samo określenie „mała proza” nie zawiera takich rozróżnień. W związku z powyższymi komplikacjami terminologicznymi przyjmuję termin „małe formy narracyjne” jako najbardziej precyzyjny, z zastrzeżeniem, że stosuję go jedynie do tekstów prozatorskich. Usprawiedliwiona uzusem, synonimicznie będę traktowała określenie „małe prozy”, poręczne ze względu na skrótowość - znów z ograniczeniem, tym razem, do tekstów narracyjnych.

${ }^{4}$ Do tego samego wniosku doszedł Piotr Fast, zob. P. Fast, Mała czy wielka forma? Pomysty do interpretacji prozy Ryszarda Kurylczyka, [w:] Małe formy prozatorskie. Anali$z y$, interpretacje, przeglady, red. W. Wójcicki, Wyd. Uniwersytetu Śląskiego, Katowice 1990, s. 102; J. Trzynadlowski, Małe formy literackie, Zakład Narodowy im. Ossolińskich, Wrocław 1977, s. 5.

5 Zob. Małe formy narracyjne, red. E. Łoch, Wyd. Uniwersytetu Marii Curie-Skłodowskiej, Lublin 1996; Małe formy prozatorskie..., dz. cyt.; Nowela - opowiadanie - gaweda. Interpretacje, red. K. Bartoszyński, M. Jasińska, S. Sawicki, PWN, Warszawa 1979; List, nowela, opowiadanie. Analizy i interpretacje, red. T. Budrewicz, H. Bursztyńska, wyd. 
Jak zauważa wymieniony badacz, określenie „małe formy literackie” konotuje niewielką objętość (ujęcie ilościowe) oraz momentalność recepcji (ujęcie psychologiczne). Sa to jednak cechy potocznie przydawane tym formom; według Trzynadlowskiego ich zasadniczy wymiar to syntetyczne pojmowanie i ujmowanie struktury tekstu, co owocuje konstrukcyjnym, zewnętrznym aspektem niewielkości małych form, czyli autonomicznością układu zdarzeniowo-fabularnego (a przez to zdolnością do kreowania sensów naddanych); nakierowaniem na puentę; uogólnieniami myślowymi ${ }^{6}$. W tej grupie tekstów, jak dalej zauważył badacz, swoiście ukształtowana jest także struktura temporalna - czas fizyczny nie pojawia się w ogóle, funkcjonuje jedynie jako konstrukcja gramatyczna lub, co istotniejsze, czas filozoficzny i historyczny ${ }^{7}$. Sygnalizuje to także kolejną właściwość poetyki małych form literackich - wielopłaszczyznowość znaczeń. Trzynadlowski wyróżnia ich trzy poziomy semantyczne: „a) warstwę znaczeń bezpośrednich (...), b) warstwę sensów - zasadniczy, podstawowy »tenor « czy też wydźwięki poszczególnej sentencji, przysłowia czy fraszki (..), c) warstwę pragmatyczną - konkretna stosowalność praktyczna danej formy..."8. Pomimo przytoczonych prób uogólnienia czynności interpretacyjnych zmierzających do sformułowania poetyki małych form literackich, Trzynadlowski konstatuje jednak, że wspólny dla nich jest w zasadzie tylko rozmiar.

Książka Piotra Michałowskiego poświęcona paralelnej problematyce, bo miniaturom w poezji współczesnej, także nie przynosi rozwiązania kluczowej kwestii - jak definiować wielkość. Badacz za miniaturę poetycką uważa bowiem „utwór zbudowany z jednego, dwóch lub najwyżej trzech tak właśnie rozumianych »zdań« (cząstek semantycznych, motywów), ściśle ze sobą powiązanych i zestawionych w sposób konieczny dla wyrazistego sensu całości"9.

Pozostaje więc uznać małe formy narracyjne za kategorię opisową, która odnosi się do tekstów intuicyjnie uznawanych za niewielkie i posłu-

II poszerzone, Wyd. Naukowe Akademii Pedagogicznej, Kraków 2001; Nowela - opowiadanie (Ewolucja gatunku), red. S. Żak, Wyd. Pedagogiczne ZNP, Kielce 1984. Istnieją także artykuły monograficzne i monografie poszczególnych gatunków. Warto przywołać chociażby Teorię i typologię opowiadania (1945-1963). Z zagadnień struktury i narracji Bogdana Pięczki (Zakład Narodowy im. Ossolińskich, Wrocław 1975) czy prace Teresy Cieślikowskiej (Nowela, Opowiadanie, oba „Zagadnienia Rodzajów Literackich” 1961, z. 1), a także Józefa Bachórza Poszukiwanie realizmu. Studium o polskich obrazkach proza $w$ okresie międzypowstaniowym 1931-1963 (Gdańskie Towarzystwo Naukowe, Gdańsk 1972).

${ }_{6}^{6}$ J. Trzynadlowski, Mate formy literackie, dz. cyt., s. 31.

7 Tamże, s. 9, 125.

8 Tamże, s. 129.

9 P. Michałowski, Miniatura poetycka, Wyd. Naukowe Uniwersytetu Szczecińskiego, Szczecin 1999, s. 125. 
gujących się minimalizmem jako swego rodzaju techniką pisarską, przez którą rozumiem ograniczenie akcji, prezentacji postaci, scenerii do elementów całkowicie niezbędnych ${ }^{10}$. Ograniczona długość tekstu wymusza porozumienie ponad tym, co napisane wprost, poprzez skonwencjonalizowane literackie znaki: toposy, style, gatunki. Konwencje literackie rozumiane jako systemy semiotyczne pozwalają więc wyposażyć małe formy narracyjne w dodatkowe znaczenia. Rezygnacja z pojęć gatunkowych, takich jak opowiadanie, nowela, anegdota, obrazek, charakter na rzecz pojemniejszej, mniej precyzyjnej kategorii wiąże się z przemianami genologii; jak piszą redaktorzy tomu The Art of Brevity:

To rozróżnienie odzwierciedla fakt, że genologia w ostatnich dekadach oddaliła się od esencjalistycznych wyobrażeń/pojęć, o tym, za co można uznać typy tekstów, mówiąc zamiast tego o gatunkach jako o szeregu tendencji i praktyk tekstowych, które są obecne w odmiennym stopniu w różnych utworach ${ }^{11}$.

Zmiana paradygmatu badawczego w badaniach nad niewielkimi objętościowo formami narracyjnymi znajduje odzwierciedlenie w praktyce nazewniczej: pojawiają się zarówno prace zbiorowe, jak i indywidualne, które, odchodząc od tradycyjnych gatunkowych określeń, sięgają po tę ogólniejszą kategorię ${ }^{12}$. Refleksja nad omawianą grupą tekstów w anglojęzycznym kręgu kulturowym obrała podobny kierunek zdecydowanie wcześniej, o czym świadczy wydawany od 1976 roku kwartalnik „Studies in Short Fiction".

Dwudziestowieczna literatura bardzo dobitnie kwestionowała wartość gatunków (by przywołać awangardę, neoawangardę, karierę form sylwicznych i hybrydycznych), a teoretycy jej wtórowali (od Crocego przez Blanchota, aż po Derridę). Jeżeli jednak zmienić perspektywę badawczą i miast szukać spójnej realizacji reguł gatunkowych, skoncentrować się na aluzjach do różnych form (zawartych w tytułach, konstrukcji świata przedstawionego, sytuacji komunikacyjnej, formie graficznej, stylu itp.), okaże się, że powojenne małe formy narracyjne tętnią mnogością przywoływanych w nich gatunków. Tym samym wchodzimy na grunt genologii rozumianej jako architekstualność, dla której gatunki stanowią istniejącą tak w świadomości piszącego, jak i odbiorcy tradycję literacką aktualizo-

10 Odwołując się do typologii minimalizmu J. Bartha, byłby to więc minimalizm materii, zob. J. Barth, Kilka stów o minimalizmie, „Ha!art” 2006, nr 24, s. 24.

11 Foreword, [w:] The Art of Brevity. Excursion in Short Fiction Theory and Analysis, eds P. Winther, J. Lothe, H.H. Skei, Columbia 2004, s. IX [przeł. M.B.].

${ }^{12}$ Małe formy narracyjne, dz. cyt., Małe formy prozatorskie..., dz. cyt., J. Smulski, Pękanie lodów. Krótkie formy narracyjne $w$ literaturze polskiej lat 1954-1955, Wydawnictwo UMK, Toruń 1995. 
waną w konkretnym utworze na najrozmaitsze sposoby ${ }^{13}$. Przywoływane w tekście formy tworzą niekiedy skomplikowany splot, który za Stefanią Skwarczyńską można nazwać instrumentacją gatunkową ${ }^{14}$.

Nawiązania do tradycji gatunkowej mają najrozmaitszy charakter, ze względu na stosunek do przywoływanej formy można jednak wyodrębnić ich cztery modele: alegacyjny (w pełni aprobatywny, co znajduje wyraz w restytucji wzorca), rozszerzająco-adaptacyjny, krytyczno-polemiczny oraz transgresyjny ${ }^{15}$. Trzy ostatnie mają charakter konwersacyjny - podejmują bowiem twórczy (aprobatywny lub negujący) dialog z tradycją ${ }^{16}$. Tym samym badania architekstualne prowadzą do postulowanej przez Grzegorza Grochowskiego semantyki form gatunkowych ${ }^{17}$, której projekt wynika także z propozycji Stanisława Balbusa18. Każde nawiązanie do historycznej formy stanowi zarazem jej interpretację, ożywienie któregoś z jej aspektów poprzez krytykę, modyfikację czy też alegację. Elementem aktualizowanym może być zarówno układ graficzny, sytuacja komunikacyjna, konstrukcja postaci czy świata przedstawionego, jak i wyposażenie kulturowe gatunku, tworzenie stałej i obligatoryjnej listy elementów tekstu nacechowanych gatunkotwórczo nie wydaje się ce-

13 Za popularyzatorów tego, wywodzącego się z badań intertekstualnych (G. Genette, L. Jenny), ujęcia w polskim literaturoznawstwie można uznać Stanisława Balbusa, Piotra Michałowskiego, Małgorzatę Mikołajczak, Ryszarda Nycza. Zob. S. Balbus, Zagłada gatunków, [w:] Genologia dzisiaj, red. W. Bolecki, I. Opacki, Wyd. IBL, Warszawa 2000; G. Genette, The Architext. An Introduction, transl. J.E. Lewin, foreword by R. Scholes, University of California Press, Berkeley 1992; tegoż, Palimpsesty. Literatura drugiego stopnia, przeł. A. Milecki, [w:] Wspótczesna teoria badań literackich za granica. Antologia, red. H. Markiewicz, t. 4, cz. 2, Wyd. Literackie, Kraków 1992; L. Jenny, Strategia formy, przeł. K. i J. Faliccy, „Pamiętnik Literacki” 1988, z. 1; P. Michałowski, Gatunki i konwencje w poezji, [w:] tegoż, Granice poezji i poezja bez granic, Wyd. Naukowe Uniwersytetu Szczecińskiego, Szczecin 2001; M. Mikołajczak, Podjać przerwany dialog. O poezji Urszuli Koziot, Universitas, Kraków 2000; R. Nycz, Intertekstualność i jej zakresy: teksty, gatunki, światy, [w:] Tekstowy świat. Poststrukturalizm a wiedza o literaturze, wyd. II, Universitas, Kraków 2000.

${ }^{14}$ S. Skwarczyńska, Wstęp do nauki o literaturze, t. 3, PAX, Warszawa 1965, s. 198-200.

15 Nawiązania o charakterze alegacyjnym, rozszerzająco-adaptującym oraz krytyczno-polemicznym zapożyczam z teorii Michałowskiego (zob. P. Michałowski, Gatunki $i$ konwencje $w$ poezji, [w:] Polska genologia literacka, red. D. Ostaszewska, R. Cudak, PWN, Warszawa 2007, s. 192; tegoż, Granice poezji i poezja bez granic, dz. cyt., s. 178-180). Model transgresyjny natomiast wyrasta z inspiracji ujęciem Laurenta Jenny'ego (zob. L. Jenny, Strategia formy, dz. cyt.): wychodząc od przywołania określonej historycznej formy w postaci rozszerzającej lub krytycznej prowadzi do jej przekroczenia, konstrukcji nowej jednorazowej (całkowicie lub w obrębie twórczości jednego pisarza) jakości.

16 Por. S. Balbus, Między stylami, wyd. II, Universitas, Kraków 1996, s. 132-142.

17 G. Grochowski, Narracja, gatunek, znaczenie, [w:] Opowiadanie w perspektywie badań porównawczych, red. Z. Mitosek, Universitas, Kraków 2004, s. 342.

18 Por. S. Balbus, Zagłada gatunków, dz. cyt. 
lowe ${ }^{19}$. Tak pojęty gatunek może stanowić zarówno kategorię interpretacyjną, jak i instrukcję lektury.

Baśń, gawęda, obrazek, anegdota, a także protokół, list czy donos stanowią oczywiste odniesienia w przestrzeni gatunkowej, ale dziennik, powieść czy epos? To już wydaje się mało prawdopodobne. Małe formy narracyjne aktualizują jednak $\mathrm{i}$ tę (wydawałoby się automatycznie dla nich zamkniętą) przestrzeń odwołań genologicznych. Co więcej, nie musi (choć może) to prowadzić ani do parodii, ani do zubożenia przywoływanego gatunku. Miniatury wielkich form narracyjnych stanowią wśród małych form narracyjnych grupę szczególną, obejmującą niewielkie prozatorskie utwory narracyjne nawiązujące do wzorców rozpoznawanych jako obszerne.

Oczywiste jest, że w przypadku problematyki architekstualnej stosunek małej formy narracyjnej do większego archetekstu, nie może mieć charakteru alegacyjnego: miniaturyzacja jest bowiem najbardziej oczywistym (także w etymologicznym znaczeniu) sygnałem modyfikacji wzorca. O tym, że nie jest to jedynie transformacja ilościowa, świadczy wielość, nie tylko metatekstowych, kwestii poruszanych w tych utworach, stąd też obok pytania o sposób przywoływania wielkich form narracyjnych w małych, kluczowa okazuje się funkcja takich zabiegów - a więc semantyczna relacja pomiędzy dwiema formami, rodzaj toczonego dialogu. Miniatury są zjawiskiem co prawda marginalnym w omawianym okresie, ale też interesującym: różnorodnym i nierzadko złożonym.

Poruszane zagadnienie nie należy do całkowicie nierozpoznanych: Skwarczyńska zwracała uwagę na miniaturyzację trzech odmian powieści w Wyjątku z listu do jednego $z$ redaktorów Mickiewicza ${ }^{20}$, Michałowski z kolei wśród miniatur poetyckich dostrzegł skróty wykorzystujące odniesienie do większego modelu, a w ich obrębie wyróżnił dwa typy: streszczenia (schematów fabularnych) oraz cytaty struktury, ograniczone jednak w ujęciu badacza tylko do elementów kompozycyjnych i wersyfikacyjnych ${ }^{21}$. Podział ten, efektywny w przypadku poezji, zastosowany wobec prozy okazuje się niewystarczający, pomija bowiem konstrukcję podmiotu, sytuacji komunikacyjnej itp. Co więcej, rozróżnienie to wydaje się niejasne, jeśli przypomnieć jak pojęcie quasi-cytatu rozumiała jego twórczyni Danuta Danek: bo czy schemat fabularny nie należy do struktury, którą da się zacytować? Propozycja Michałowskiego budzi także wątpliwości, ponieważ badacz nie podejmuje problemu kluczowego dla tej

19 Zob. V.B. Leitch, (de) coding (generic) discourse, „Genre” 1991, vol. 24, no 1, s. 84.

20 S. Skwarczyńska, Wstęp do nauki o literaturze, t. 3, dz. cyt., s. 236.

${ }^{21}$ P. Michałowski, Miniatura poetycka, dz. cyt., s. 186-187. 
kategorii w ujęciu Danek - dystansu pomiędzy cytowaną formą a jej kontekstem $^{22}$.

Możemy sięgnąć jednak w tym przypadku po Peirce'owską teorię oraz klasyfikację znaków i, wychodząc od założenia o znakowym charakterze rzeczywistości, spojrzeć na miniaturę jako na reprezentamen, który odnosi się do referentu (wielkiej formy narracyjnej), a pośredniczy pomiędzy nimi i równocześnie powstaje na ich styku interpretant, rozumiany jako interpretacja przedmiotu zawarta w środku przekazu, stanowiąca o odrębności znaku. A ponieważ kluczowy dla miniatur prozatorskich wydaje się właśnie sposób odnoszenia się tych pierwszych do obszernych gatunków, przydatna okazuje się klasyfikacja znaków przeprowadzona przez Peirce'a na podstawie powiązania między środkiem przekazu a referentem. Wśród nawiązań do wielkich form narracyjnych w obrębie małych można więc wyróżnić dwa rodzaje: o charakterze indeksalnym, oparte na bezpośrednim wskazywaniu, oraz nawiązania ikoniczne - bazujące na podobieństwie. Te pierwsze odwołują się do większego gatunku poprzez kreację jego fragmentu (np. kilka kartek z dziennika w $Z$ pamiętnika Piotrusia Sławomira Mrożka lub epizod z eposu w Eposie Teodora Parnickiego), w przypadku ikonicznych znaków wielkich form mówimy natomiast o cytatach całej struktury, które ze względu na napięcie pomiędzy niewielką objętością tekstu a skomplikowaniem wzorca sprawiają wrażenie streszczenia (np. Saga Barbary Czałczyńskiej, Cena sławy Mrożka, Chińskie pudełeczko Anatola Sterna). Nie oznacza to oczywiście (co wymaga podkreślenia), by znaki indeksalne gatunku nie opierały się na cytacie struktury - podstawa ta jest wspólna obu formom nawiązań, z tym że te pierwsze odwołujA się do wybranych elementów przywoływanych całości - i kreują ich fragmenty.

\section{Fragments are the only forms I trust ${ }^{23}$}

Indeksalne odwołania do wielkich form narracyjnych przybierają postać fragmentu kreowanego (używając określenia Kazimierza Bartoszyńskiego ${ }^{24}$ i zdecydowanie dominują wśród omawianej prozy. Dobrym celem dla tak pojętej aluzji literackiej okazują się formy diariuszowe:

22 D. Danek, O cytatach struktury (quasi-cytatach), [w:] taż, O polemice literackiej w powieści, PIW, Warszawa 1972.

${ }^{23}$ R. Barthelme, See the Moon?, [w:] Unspeakable Practices, Unnatural Acts, Farrar Straus and Giroux, New York 1968.

${ }^{24} \mathrm{~K}$. Bartoszyński, O fragmencie, [w:] Między tekstami. Intertekstualność jako problem poetyki historycznej, red. J. Ziomek, J. Sławiński, W. Bolecki, PWN, Warszawa 1992, s. 75 . 
konstrukcja, na którą składają się wyodrębnione dzienne zapiski połączone często tylko tożsamością podmiotu mówiącego, jest łatwa do kreowania w mniejszej postaci. Na fragmentaryczny charakter częstokroć wskazywać ma sam tytuł [np. $\boldsymbol{Z}$ pamiętnika Piotrusia (1953), $\boldsymbol{Z}$ gawęd wuja (1957), $\boldsymbol{Z}$ notatnika kapitalisty (1990-1993) Sławomira Mrożka, Lokator szklanego domu (Urywek z pamiętnika) (1970) Anatola Sterna, wyróżnienie - M.B.]. Nie oznacza to jednak, byśmy w rzeczywistości mieli do czynienia $\mathrm{z}$ formami otwartymi pod względem kompozycji. Omawiane teksty cechuje co prawda wprowadzenie in medias res (jako swoisty znak fragmentaryczności), fabuły mają jednak wyrazistą, zamkniętą konstrukcję: zawiązanie, rozwinięcie, niekiedy perypetię oraz rozwiązanie, co wywołuje wrażenie całości. Zakończenia o charakterze zamkniętym (z taką sytuacją spotykamy się w pierwszym ze wspomnianych tekstów Mrożka, Eposie Parnickiego (1958) czy Makaron, piraci, hajże na ribeire! Zygmunta Fijasa (1986) niekiedy wzmocnione są nawet puentą językową. Jedynie przekonanie (ugruntowane na uzusie) o tym, że dziennik czy pamiętnik to formy obszerne, dowodzi fragmentaryczności tych zapisków ${ }^{25}$.

$\mathrm{W}$ analizowanych formach pojawia się więc napięcie pomiędzy aktualizowanym w horyzoncie oczekiwań czytelniczych nastawieniem na długie trwanie całości lub niekompletność a otrzymywanym zwartym tekstem stanowiącym z perspektywy kompozycji zamkniętą całość. Kontrast ten może mieć jednak i inne oblicze: wczesne miniatury form dziennikowych autorstwa Mrożka zamiast przedstawiać intymny świat narratora bądź spojrzenie na rzeczywistość naznaczone piętnem indywidualności, okazują się czystą akcją. Niezwykle dynamiczna, zwarta, choć dość ogólnie przedstawiona sprawia, że omawiana grupa tekstów zbliża się niekiedy do sprawozdania, efekt ten podkreśla jeszcze styl (dominują proste, nierozwinięte zdania). Czy oznacza to jednak, że dziennikowa forma jest jedynie kostiumem (dość nieudolnie skrojonym i zbędnym) dla zwykłego opowiadania? Niekoniecznie. Mimetyzm formalny, który obserwujemy $\mathrm{w}$ tych utworach, kreuje bowiem formę naśladowaną, wybierając $\mathrm{z}$ przywoływanego wzorca tylko niektóre elementy ${ }^{26}$. Zastosowanie dziennika z jego wąską perspektywą czasową, ograniczeniem fokalizacji do jednego

25 O pozornej jedynie kompozycji otwartej świadczy także konstrukcja dat w przypadku utworów odwołujących się do dziennika, jak np. w $Z$ pamiętnika Piotrusia: pierwszy z zapisków oznaczony jest dniem, miesiącem oraz rokiem, w zapiskach z kolejnych dni brakuje ostatniej informacji. Tym samym pierwsza data pełni rolę sygnału delimitacyjnego równoznacznego ze zdaniem: „Działo się to 16 grudnia 1950 roku” - a następne informacje o czasie akcji można by zastąpić formułą „następnego dnia” - fragmentaryczność okazuje się więc jedynie kreowana.

${ }^{26}$ Zob. J. Lalewicz, Mimetyzm formalny $i$ problem naśladowania $w$ komunikacji literackiej, [w:] Tekst i fabuła, red. Cz. Niedzielski, J. Sławiński, Zakład Narodowy im. Ossolińskich, Wrocław 1979. 
podmiotu w połączeniu z zajmowaną przez niego pozycją innego (dziecka w $Z$ pamiętnika Piotrusia, niepokornego w swym nadmiernym posłuszeństwie obywatela w $\dot{Z} y c i u$ współczesnym czy przybysza w $Z$ notatnika kapitalisty), innego, który nie do końca pojmuje otaczającą go rzeczywistość, pozwala wprowadzić efekt wyobcowania i odrealnienia, którego nie przełamuje odautorska narracja. Tym samym miniaturyzacja takich gatunków jest sfunkcjonalizowana i okazuje się jeszcze jedną formą kształtowania charakterystycznych dla Mrożka struktur parabolicznych - o czym później.

Czy jednak rzeczywiście wszystkie wymienione wcześniej utwory odnoszą się właśnie do dziennika: tytuły, takie jak $Z$ pamiętnika Piotrusia (1953) czy $Z$ notatnika kapitalisty (1990-1993) wskazują na inne formy bądź w ogóle nie odnoszą się do żadnego gatunku [Życie wspótczesne (1957)]. Wydaje się, że w pierwszym przypadku sprawa jest bezdyskusyjna: dystans narracyjny jest niewielki, a zapiski rozpoczynają się od dat. $Z$ notatnika kapitalisty stanowi przypadek nieco bardziej złożony; tekst tytułem odsyła do codziennej, afabularnej formy składającej się z formalnie i treściowo najróżniejszych zapisków, utwór Mrożka natomiast zbudowany jest $\mathrm{z}$ niewielkich, wyodrębnionych graficznie całostek fabularnych opisujących kolejne dni pobytu przybysza w Europie Wschodniej. Pomimo braku datacji można określić czas akcji na rok około 1990, tajemniczy przybysz to bowiem wcielenie kapitalistycznego krwiopijcy wzbogaconego o atrybuty jego bardziej zadomowionego w literaturze (zwłaszcza popularnej) kuzyna - wampira, co daje komiczny efekt:

Nareszcie! Wybiła godzina, gdy znowu będę ssał krew ludu bezkarnie. Mam na myśli lud wschodnich krajów Europy, bo na zachodnich zawsze ssałem do woli. A teraz żadnych już przeszkód, a nawet sami do ssania zapraszają. Wkładam cylinder i jadę! [III, s. 466] $]^{27}$.

Ten pierwszy fragment od początku buduje odniesienie do form intymistycznych: pierwszoosobowa narracja jest skoncentrowana na doznaniach i przemyśleniach podmiotu, silnie nasycona emocjami, przedstawia indywidualny (aż do skrajności) punkt widzenia, dystans narracyjny jest minimalny. Następne zapisy, choć nieoznaczone datami, tworzą relację podobną do dziennikowej: to coraz krótsze relacje z pobytu, świadczące o stopniowym rozczarowywaniu się wampirzym eldorado. Wysysanie krwi z ludów wschodnich okazuje się nierealne: „Propozycja, żebym zainwestował w telekomunikację. Zapytałem, ile z tego będę miał. Obiecali,

27 S. Mrożek, Opowiadania, t. 1-3, Noir sur Blanc, Warszawa 1999. Wszystkie cytaty na podstawie tego wydania, w nawiasie za cytatem cyframi rzymskimi podaję oznaczenie tomu, a arabskimi numer strony. 
że odpowiedzą telefonicznie, jak im założę telefon" [III, s. 466]. Temat zapisków szybko staje się bardziej osobisty: „Czuję się nie najlepiej, poszedłem do lekarza, który stwierdził katar ssawki. Radził zmienić klimat” [III, s. 466]. Tajemnicza choroba powoduje powrót na Zachód i lekarski zakaz wyjazdów. Otrzymujemy więc swoisty wampirzo-kapitalistyczny dziennik podróży na Wschód, w którym charakter atrakcji, swoistych dziwów kultury pełnią gdzie indziej niespotykane zjawiska rynkowe.

W Życiu wspótczesnym (1957) na dziennikowy adres architekstualny wskazuje inicjalna rama tekstu: „Jako lojalista postanowiłem jeden dzień przeżyć w duchu języka oficjalnych wypowiedzi” [I, s. 254] oraz graficzne wyodrębnienie częśsi właściwej, a także pełniące funkcję delimitacyjną śródtytuły: Dzień pierwszy i Dzień drugi. Wbrew zapowiedzi jednak nie jeden dzień jest opisany, a kilka kolejnych - druga narracja bowiem po paru zdaniach staje się opowiadaniem o enigmatycznym „zagadnieniu”. Obserwujemy więc jakby pisanie $\mathrm{w}$ toku ${ }^{28}$ : początkowy plan jednorazowego, eksperymentalnego stworzenia zapisku samodzielnej kartki z dziennika przeradza się (siłą inercji jednostkowej, społecznej - a co najbardziej prawdopodobne - gatunkowej) w początek regularnego dziennika, sabotowanego z kolei przez owo „zagadnienie”, które staje się ośrodkiem konkurencyjnego wobec podmiotowego wątku. Tym samym dostrzegamy nie tylko determinizm gatunkowy (uzależniające właściwości, atrakcyjność form diariuszowych), ale także zainscenizowany proces opisywany przez Jerzego Ziomka w Genera scribendi: narodziny formy literackiej z intymistycznej, nieliterackiej ${ }^{29}$. O otwartości tego procesu (i dalszych możliwych metamorfozach) świadczy brak paralelnego wobec inicjalnego obramowania tekstu w zakończeniu czy innego sygnału delimitacyjnego.

W tej przestrzeni i typie nawiązań mieściłyby się także wielokrotnie wskazywane przez badaczy nawiązania Białoszewskiego do formy dziennikowej, którym ze względu na rozległy stan badań nie poświęcę wiele uwagi ${ }^{30}$, wskazując jedynie na różnice w przywoływaniu i wykorzystaniu

${ }_{28}$ Nie odwołuję się do kategorii dzieła w ruchu Umberta Eco, w przypadku tego utworu mamy bowiem do czynienia z tekstem o skończonej, ustrukturyzowanej i utrwalonej postaci materialnej, a rola czytelnika nie polega na rekonstrukcji całości. Por. U. Eco, Poetyka dzieła otwartego, przeł. J. Gałuszka, [w:] tegoż, Dzieło otwarte. Forma i nieokreśloność w poetykach wspótczesnych, Czytelnik, Warszawa 1994. Można jednak Życie wspótczesne określić jako dzieło czy pisanie w toku, ponieważ imituje proces powstawania utworu: od zamiaru poprzez różne koncepcje całości ewoluujące pod wpływem sytuacji zewnętrznej i zmian w świadomości narratora. Tekst ten byłby więc bliski mimetyzmowi procesu i autotematyzmowi.

${ }^{29}$ Por. J. Ziomek, Genera scribendi, „Pamiętnik Literacki” 1992, z. 1.

${ }^{30}$ A. Zieniewicz, Małe iluminacje. Formy prozatorskie Mirona Białoszewskiego, PIW, Warszawa 1989, s. 29; M. Głowiński, Małe narracje Mirona Białoszewskiego, [w:] tegoż, Gry powieściowe. Szkice $z$ teorii $i$ historii form narracyjnych, PWN, Warszawa 1973, s. 338; M. Frączak, Możliwość i niemożliwość rzeczywistości, „Kresy” 2001, nr 3, 251-253; A. Zaga- 
tego gatunku przez autora Donosów rzeczywistości oraz Mrożka. Kartka z dziennika, pojawia się u tego pierwszego jako samodzielny utwór, a co za tym idzie, stanowi wartość samoistną (ślad przeżycia niezapomnianego, jednostkowego, „fragment małej potoczności” 31 łączącej autobiografizm i codzienność, subiektywną perspektywę i zewnętrzne realia), a cały dziennik - strukturę nadrzędną [w Donosach rzeczywistości ${ }^{32}$ (1973)], spajającą najróżniejsze tematy, konwencje, style, ale też - formę otwartą. W zestawieniu z takim ujęciem praktyka Mrożka okazuje się prowadzić do uprzedmiotowienia tego gatunku.

Dziennik wydaje się stwarzać najwięcej możliwości miniaturyzowania na zasadzie indeksalnej, pozwala bowiem w interesujący i umotywowany sposób przedstawić pełną i wieloznaczną fabułę (oczywiście przy zachowaniu dużej ogólności). To jednak nie jedyna obszerna forma przywoływana na tej zasadzie. Mrożek pokusił się o miniaturyzację antologii sentencji, kroniki oraz intelektualnej autobiografii. Konstrukcja tej pierwszej paralelna jest wobec aluzji dziennikowych: mamy bowiem do czynienia ze strukturą zbudowana z całostek - tym razem jednak o zdecydowanie większej autonomii - która znajduje przeciwwagę w ciągłości ustanawianej poprzez grupowanie zdań na zasadzie tematycznej. Złote myśli $i$ sentencje (1957) obejmują taką problematykę, jak O Murzynach, O florze, O faunie $i$ w ogóle o świecie przyrody, pojawiają się jednak i tradycyjne dla tego typu wydawnictw kategorie: $O$ sztuce czy $O$ człowieku. Jeżeli przyjrzeć się poszczególnym zdaniom, Mrożek prezentuje aforyzmy, wśród których dominują definicje, jak np. „Zawód miłosny: gdy nekrofil znajdzie partnera, który jest w letargu" [I, s. 306]. Pojawiają się także paradoksy (np. „Nie w każdej muszli słychać morze” [I, s. 305]), pytania retoryczne oraz aforyzmy posługujące się formami użytkowymi: sloganu („Rolniku! Myj zęby!” [I, s. 305]) czy tekstów popularnonaukowych „Dobrze wychowany (kulturalny) krajowiec nie mówi »twoja być« (np. »Twoja być biała«), ale »Pańska być« (np. »Pańska być biała«)" [I, s. 304] ${ }^{33}$.

jewski, W Warszawie jak na wsi, „Znak” 1977, z. 11-12; R.K. Przybylski, Dziennik albo rzeczywistość bez kresu, „Nurt” 1977, nr 11, s. 38; I. Baryga, Donosy rzeczywistości Mirona Białoszewskiego, „Prace Polonistyczne” 1982, seria 38; A. Stawiarska, Źródła gatunkowe „matych narracji” Mirona Białoszewskiego, „Studia i Materiały. Filologia Polska” 1995, t. 7; E. Łubowicz pisała z kolei o Szumach, zlepach, ciagach jako kontynuujących konwencję pamiętnika, zob. E. Łubowicz, Z pozycji „obok”, „Odra” 1977, nr 5, s. 106.

${ }^{31}$ A. Zieniewicz, Małe iluminacje..., dz. cyt., s. 7-8.

32 Jedynie w tym tomie próz Białoszewski konsekwentnie na początku każdego utworu mniej lub bardziej dokładnie zapisuje datę. W Szumach, zlepach, ciagach (1976) takie oznaczenia pojawiają się epizodycznie, podobnie w Matych i większych prozach (2000) oraz Rozkurzu (1998).

${ }^{33} \mathrm{Na}$ temat typologii aforyzmów zob. P. Michałowski, Aforyzm, [w:] Miniatura poetycka, dz. cyt. 
Większość zdań składających się na Złote myśli $i$ sentencje opiera się na grze słów, toteż adekwatne wydaje się nazywanie ich aforyzmami, które stanowią „zwięzłe, błyskotliwe wypowiedzi (...) zabarwione dowcipem o najróżniejszych odcieniach i wyrażone w niezwykle efektownej formie" 34 . Brakuje jedynie tytułowych sentencji. Ciągle problematyczna wydaje się także tematyka zdań - nie przystająca do żadnego $\mathrm{z}$ wymienionych gatunków, trudno bowiem uznać, by traktowały o kwestiach moralnych, filozoficznych czy psychologicznych ${ }^{35}$. Jednocześnie odwołania do form bazujących na autorytecie (sloganów, pisarstwa popularnonaukowego, ale także definicji) skłaniają do wniosku, że to rzeczywiście sentencja (czyli: „zdanie zawierające ogólną myśl (...) sformułowane w sposób wyrazisty i skłaniający do uznania jego bezwzględnej trafności"36 [wyróżnienie - M.B.]), ale sparodiowana. Tym silniej ukazany jest więc fałsz uroszczeń tego gatunku do wielkich słów i wielkich prawd, które stanowią jedynie słowa - dowcipne, bon moty. Krytyczno-polemiczne nawiązanie do gatunku przybiera $\mathrm{w}$ tym przypadku charakter parodii o funkcji krytycznej, co jest stosunkowo częste w miniaturach wielkich form narracyjnych, a nagminne, jeśli wyszły spod pióra Mrożka ${ }^{37}$.

Ciekawszy przypadek przedstawiają zacytowane fragmenty kroniki w Uwagach historycznych Mrożka (1953). Brakuje co prawda inicjalnych oznaczeń rocznych (typowych dla tej formy piśmiennictwa), jednak cudzysłów sygnalizujący, że są to tylko wyimki, usprawiedliwia ten niedostatek. Oba teksty posługują się archaizacją obejmującą leksykę, fleksję oraz składnię, stylizacji podlega także świadomość podmiotu piszącego oraz cała sytuacja komunikacyjna: relacja o rycerskim męstwie przeznaczona dla potomnych, powstała w podzięce za darowane klasztorowi włości. Jedyna niezgodność z konwencją gatunkową to paralelizm kronik spisanych tą samą ręką. Obie opowiadają tę samą historię, jednak ku chwale dwóch różnych panów. W pierwszej zwycięzcą jest „Garland szlachetny”, w drugiej "Gwido promienisty”, w obu oponent przedstawiony jest jako rozbójnik, który napadł na kupców jedwabnych, a sławiony jako dobry chrześcijanin lubujący pokój. W relacjach jedno tylko się zgadza: kupcy zostali wymordowani, a jedyny ocalały otrzymał schronienie w klasztorze. Wyjaśnienie tej dziwnej i sprzecznej z konwencją kroniki struktury, znajdujemy w tytule całości, który brzmi Uwagi historyczne. Niedo-

${ }^{34}$ K. Orzechowski, Aforyzm, [hasło w:] Stownik rodzajów i gatunków literackich, red. G. Gazda, S. Tynecka-Makowska, Universitas, Kraków 2006, s. 7. Por. też: J. Sławiński, Aforyzm [hasło w:] Słownik terminów literackich, red. A. Okopień-Sławińska, M. Głowiński, J. Sławiński, Zakład Narodowy im. Ossolińskich, Wrocław 1988, s. 15.

35 Por. J. Sławiński, Sentencja, [hasło w:] Słownik terminów literackich, dz. cyt., s. 464.

36 Tamże.

${ }^{37} \mathrm{Na}$ temat funkcji parodii zob. R. Nycz, Parodia i pastisz. $Z$ dziejów pojęć artystycznych w świadomości literackiej XX wieku, [w:] tegoż, Tekstowy świat..., dz. cyt., s. 219. 
bitek, uznany przez opata za opętanego, twierdził, że to obaj panowie niezależnie od siebie napadli na kupców. Mamy więc do czynienia nie tylko z nawiązaniem do kroniki, ale i do eseju historycznego - najpewniej z zakresu jej teorii. Brakuje co prawda śladów dyskursywności, jednak zestawienie dwóch narracji sprzecznych w zakresie przekazywanej wersji historii i intencji piszącego łącznie traktują o perspektywizmie w kształtowaniu wizji przeszłości, jej uwarunkowaniach kulturowych, ekonomicznych i tekstowych, a (meta)historyczne uwagi są w zasięgu myśli każdego czytelnika za sprawą przykładu. Tekst ten ma więc kompozycję ramową: na pierwszym planie (na prawach swoistej hipotezy interpretacyjnej) esej historyczny sygnalizowany przez tytuł i zestawienie tekstów, na drugim cytowane znaki indeksalne kroniki ${ }^{38}$.

Jednak (wbrew pozorom) niejeden Mrożek tworzył miniatury. Parnicki jest autorem mało znanego tekstu o tytule Epos (1958). Obdarzył nim krótki utwór prozatorski, posługujący się narracją personalną, w którym liczne i długie partie mowy pozornie zależnej tworzą strumień świadomości. Nie oznacza to jednak, by związek pomiędzy tytułowym gatunkiem a tekstem nie istniał - mamy bowiem do czynienia $\mathrm{z}$ trawestacją epizodu z piątej pieśni Iliady: starcia Diomedesa z Pandarem. Fragmentaryzm podkreślony jest wprowadzeniem in medias res, a dokładniej w sam środek bitwy, gdzie „Okiełznać rozhukane konie nie było rzeczą łatwą" [s. 9] ${ }^{39}$, jak głosi pierwsze zdanie. Nie pojawiają się żadne wyjaśnienia dotyczące miejsca, czasu, dotychczasowego przebiegu akcji identyfikacja intertekstu czyni te informacje całkowicie zbędnymi. Dominantą kompozycyjną jest jednak postać, a nie fabuła czy totalność świata przedstawionego $0^{40}$, prezentowana scena poprzez typ narracji traci także charakter zamkniętej i odległej, wymusza bliższą relację pomiędzy postacią, narratorem a czytelnikiem, który staje się świadkiem współodczu-

38 Ale nie tylko: Uwagi historyczne składają się z trzech części. Obok Dwóch kronik pojawia się historia Szczęścia pazia Jana, demistyfikująca narracja o miłości średniowiecznego młodzieńca do pięknej księżniczki poznanej za pośrednictwem pieśni trubadurów; paź rozczarowany jednak zbyt namiętną ukochaną, ucieka od niej. Ostatnią częścią tryptyku jest Sztabskapitan Hipolit, opowieść o poborowym, który w kolejnych kampaniach i wojnach, ponosząc rany, awansuje, ale wojna go stopniowo degeneruje i degraduje w człowieczeństwie: Hipolit traci władze umysłowe, zdolność odczuwania emocji, a w końcu umiera stratowany przez wojsko. Znów powołany, dzielnie służy, wyzbyty już jednak całkowicie nawet fizycznych potrzeb i właściwości: pije wodę z bagna, a w końcu staje się ośką w taborach. Zakończenie tego opowiadania stanowi zarazem puentę całości: „A potem nikt już nie słyszał o sztabskapitanie Hipolicie. Taka to historia” [I, s. 86], podkreślającą fikcjonalność i absurdy dyskursu historycznego oraz szaleństwo historii.

39 T. Parnicki, Opowiadania, PAX, Warszawa 1958. Wszystkie cytaty na podstawie tego wydania, numer strony podaję w nawiasie za cytatem.

${ }^{40}$ Por. S. Skwarczyńska, Epos i powieść. Essai, [w:] taż, Z teorii literatury. Cztery rozprawy, Poligrafika, Łódź 1947, s. 159-160. 
wającym i słuchającym najintymniejszych myśli bohatera41. Diomedes Parnickiego, podobnie jak ten Homera, cechuje się odwagą graniczącą $\mathrm{z}$ brawurą, niezwykłą sprawnością w wojennym rzemiośle, umiłowaniem ziemi ojczystej. To jednak całkowicie odmienny bohater: o ile ten antyczny zabija Pandara, by pomścić pierwszą ranę, o tyle współczesny szuka na polu bitwy godnego przeciwnika, takiego, który nadałby jego śmierci sens. Jednak w decydującej chwili bezpośredniego zagrożenia zamiast podekscytowania, lęku, pewności tryumfu doświadcza dojmującego poczucia bezsensu:

Chce mu się tylko płakać. Sam nie wie dlaczego. Czuje, że jeżeli nie powstrzyma ich siłą woli, łzy trysną mu z oczu. Ach, to słońce... Jakże powoli się ruszamy... jak piękny jest Eneasz... jak głupio śmieje się Pandar, a przecież jemu się zdaje, że mądrze, że chytrze... [s. 10].

Taka wizja pojedynku antycznych herosów, prezentująca nieuświadamiane wcześniej postawy egzystencjalne, możliwa jest tylko dzięki przyjęciu perspektywy antropocentrycznej i świeckiej. Z Eposu nie darmo została wymazana Pallas Atena, wierna opiekunka i sprawczyni zwycięstwa Diomedesa w Iliadzie, ale także inni bogowie i ich dary - znika więc charakterystyczne dla eposu współwystępowanie świata nadprzyrodzonego i ludzkiego.

Indeksalnym odniesieniem architekstualnym mogą być także gatunki cechujące się większą niż dotychczas omawiane ciągłością i zwartością. Zawarcie obszernej i polimorficznej powieści w małej formie wydaje się niemożliwe - jednak teksty Fijasa, Głowińskiego, Mrożka, Sterna dowodzą, że tak nie jest. Wymienieni twórcy zacytowali fragmenty najsilniej wyeksponowane i skupiające najwięcej elementów charakterystycznych (Mrożek i Fijas zakończenie, Głowiński i Stern początek), a także odmiany powieści popularnej (Mrożek i Fijas marynistycznej powieści przygodowej, a Głowiński historycznej). Wybór ten nie jest bez znaczenia - gatunki literatury popularnej są najsilniej uschematyzowane, więc najłatwiej rozpoznawalne, tak że w dobie kryzysu gatunków jedynie genologia literatury popularnej święci tryumfy ${ }^{42}$. W przypadku Mrożka mamy do czynienia ponownie $\mathrm{z}$ kreowanym fragmentem parcjalnym, o czym świadczy wprowadzenie in medias res, ograniczenie fabuły (poszukiwania skarbu) do samego wykopywania legendarnych bogactw; konwencja podpowiada jednak, że wcześniej musiał nastąpić ciąg wydarzeń, dzięki któremu bohaterowie weszli w posiadanie mapy; prawdopodobnie jakiś rejs, dzieje przyjaźni Gucia i narratora, być może nawet znajomość z Morganem.

${ }^{41}$ Zob. M. Bachtin, Epos i powieść (O metodologii badań nad powieścia), [w:] Problemy literatury i estetyki, przeł. W. Grajewski, Czytelnik, Warszawa 1982.

42 Por. A. Martuszewska, „Ta trzecia”. Problemy literatury popularnej, Wyd. Uniwersytetu Gdańskiego, Gdańsk 1993, s. 15. 
Podobnie skonstruowany jest tekst Fijasa Makaron, piraci, hajże na ribeire!43 (1986) wprowadzający w rodzące się na pirackim okręcie obsesyjne pragnienie makaronu, tym razem mamy jednak do czynienia $\mathrm{z}$ fragmentem strukturalnym ${ }^{44}$. Na poprzedzającą ten fragment całość wskazują wyznaczniki leksykalne, ale także horyzont oczekiwań czytelnika: rejs zapewne jest długi i wyczerpujący, a piratów łączą skomplikowane relacje oparte na przyjaźni, nienawiści, zapewne istnieje też geneza absurdalnego zakazu spożywania makaronu.

Powieść z życia wyższych sfer Głowińskiego 45 (1998) to natomiast, jak można podejrzewać zgodnie $\mathrm{z}$ regułami gatunku, sama ekspozycja (społecznego tła akcji) w postaci strumienia świadomości jadacej powozem hrabiny. Taka prezentacja zostawia szerokie pole dla najróżniejszych pododmian gatunkowych - przedstawienie znajomych pozwala, by wyobrażać sobie melodramatyczny, romansowy czy przygodowy ciąg dalszy.

Stern w Początku powieści pisanej przez kobietę (1970) już tytułem sygnalizuje rodzaj fragmentu - rzeczywiście mamy w tym przypadku do czynienia z ekspozycją, jednak raczej nie całą. Sygnalizuje to trzykropek na początku utworu, ale także tajemniczość rodzącego się konfliktu między narratorką (i zarazem bohaterką) oraz jej mężem sugeruje odmienny charakter wcześniejszego status quo - owego dwukrotnie wspomnianego roku małżeństwa. Mocna koda w zakończeniu tego utworu („Tak się rozpoczął nowy rozdział w moim życiu. Gdybym była Dantem, opisałabym je i nazwałabym PIEKŁEM"46 [s. 114]) sygnalizuje (paradoksalnie, ale i konwencjonalnie) początek nowego etapu w życiu postaci, a co za tym idzie - kolejnego elementu kompozycyjnego (rozwinięcia), którego Stern zgodnie z tytułową zapowiedzią już nie przytacza.

\section{Niemożliwe gatunki}

Obok indeksalnych nawiązań do wielkich form narracyjnych występują także epizodyczne aluzje o charakterze ikonicznym. Stanowią one swoistego rodzaju cytaty struktury z równoczesnym zagęszczeniem cech wzorca. Dystans rodzi się tutaj pomiędzy przywoływaną formą a bardzo

43 Utwór pochodzi z cyklu Przekłady z nogi na nogę, z tomu Tylko dla poważnych, Wyd. Łódzkie, Łódź 1986.

${ }^{44}$ Zob. K. Bartoszyński, O fragmencie, dz. cyt., s. 75.

45 Utwór pochodzi z tomu Przywidzenia i figury. Małe szkice 1977-1997, Wyd. Literackie, Kraków 1998.

46 Wszystkie cytaty na podstawie wydania Historie $z$ nieco innych wymiarów, Iskry, Warszawa 1970. 
wąskim kontekstem - zazwyczaj ograniczonym do tytułu. Zasadniczy jednak znak nieufności wobec cytowanej wielkiej formy uwidacznia się w samej procedurze streszczania jej - tak jakby nie była warta (lub możliwa do realizacji) w swej pełnowymiarowej postaci ${ }^{47}$.

Cena sławy (1990-1993) Mrożka stanowi streszczenie schematu fabularnego marynistycznej powieści przygodowej. Pojawia się jednozdaniowa ekspozycja: „Wielu było sławnych piratów na Morzu Karaibskim, ale kapitan Morgan był najsławniejszy", następnie dwuzdaniowe zawiązanie akcji: „Aż do czasu, kiedy sława Pedro Canibala zaczęła dorównywać jego sławie. I powstało między nimi współzawodnictwo o tytuł najsławniejszego pirata". Dalej rozwinięcie, które mogłoby przynieść zagładę wielu drzewom, Mrożek jednak ekologicznie je streszcza:

Kapitan Morgan zakradł się pod osłoną nocy do niezdobytej fortecy Santa Rita La Mayor i wziąwszy do niewoli jej komendanta, wycofał się przed świtem. Ale Pedro Canibal porwał wicekróla w samo południe i na dodatek podpalił miasto [III, s. 299].

Spirala przemocy i rywalizacji trwa przez kolejne cztery akty terroru. Co znamienne jednak i widoczne już w powyższym cytacie - zdania relacjonujące bogate są w detale, które mogą służyć do rozwijania ich przez czytelnika w pełnowymiarową opowieść. Dalsza część fabuły także zbudowana jest zgodnie $\mathrm{z}$ klasycznymi zasadami: następuje perypetia, najszerzej jednak zaprezentowana. Eskalacja przemocy zostaje przerwana, obaj kapitanowie ścigają ten sam statek wyładowany złotem i dziewicami. Canibal dopada go, by nie doliczyć się jednego dukata, jednej dziewicy i znaleźć notkę: „RESZTA DLA PANA” [III, s. 300] - popis brawury i wspaniałomyślności Morgana, ale przede wszystkim całkowitego zadufania i największa obraza dla rywala. Fragment ten najsilniej przykuwa uwagę: jest najobszerniejszy, napięcie jest więc stopniowane, a efekt zaskoczenia tym większy, że punkt widzenia ( $\mathrm{w}$ rozumieniu Borysa Uspienskiego48) pokrywa się z horyzontem Canibala. Wydaje się jednak, że decydującą rolę odgrywa tutaj twórcze i przewrotne wykorzystanie wcześniej eksploatowanego i prezentowanego schematu fabularnego. Lapidarność epizodu nadaje mu charakter puenty fabularnej, która w pełnowymiarowej powieści jako kolejna przygoda nieustraszonego kapitana

${ }_{47}$ Temu streszczeniu towarzyszy więc zmiana znaczenia oryginału, niemożliwa w zwyczajnym, zob. W. Marciszewski, Sposoby streszczania i odmiany streszczeń, „Studia Semiotyczne" 1970, t. 1.

48 Zob. B. Uspienski, Poetyka kompozycji. Struktura tekstu artystycznego i typologia form kompozycji, przeł. P. Fast, Śląsk, Katowice 1997. 
Morgana zapewne straciłaby całą moc. Tutaj jest ona na tyle długa, by zbudować horyzont oczekiwań i trwa na tyle krótko, by tym skuteczniej go zawieść. Co więcej, Mrożek niejako pokazuje prawdopodobne wytracenie impetu puenty w powieści, dodając rozwiązanie akcji w postaci samobójstwa Canibala.

Elementem cytatu struktury jest jednak nie tylko schemat fabularny tej popularnej odmiany powieści, ale i konstrukcja świata przedstawionego, półtorej strony tchnie obcością: Cena sławy pełna jest galeonów, egzotycznych zwierząt i obcobrzmiących nazw własnych. Nazwiska postaci należą albo do tradycyjnego repertuaru tego gatunku (kapitan Morgan), albo stanowią imiona znaczące - też naznaczone egzotyką poprzez pisownię (Canibal).

Stern w krytyczno-polemicznym ferworze stworzył natomiast Chińskie pudełeczko (Schemat powieści psychologicznej) (1970). To ikoniczne nawiązanie jest o tyle ciekawe, że nie ogranicza się do streszczenia fabuły (co w przypadku tej odmiany powieści byłoby trudne, być może bezwartościowe, biorąc pod uwagę, że bywa ona albo nieistotna albo zredukowana do minimum), ale kreuje charakterystyczny typ narracji: mowę pozornie zależną tworzącą strumień świadomości. Opowiadanie relacjonujące z pierwszego zdania („Wchodzi zrozpaczony: zerwał”) już w drugim przemienia się w prezentację jego myśli („Tym razem na zawsze. Świat stracił całą swoją kolorowość. I zdradził tamtą kobietę. Którą też stracił” [s. 52]). Chaotyczność tych zdań, zatarte związki przyczynowo-skutkowe są konsekwencją $\mathrm{w}$ równej mierze schematyczności, skrótowości narracji, co cechą strumienia świadomości. Kompozycja całości tak streszczonego utworu obejmuje następujące elementy (i ich układ zgodny z konwencją gatunkową): wprowadzenie in medias res, ciąg zdarzeń (o charakterze erotycznym) teraźniejszych, które odbijają się w świadomości postaci oraz wywoływanych z niej retrospekcji, a także fragmenty refleksyjne na temat istoty zdrady, prowadzące do niekonkluzywnego zakończenia. Zarówno więc rodzaj przedstawionych treści, jak i sposób ich przedstawienia wskazuje na otwarty, fluktuacyjny charakter ludzkiej psychiki.

Inny ciekawy przykład ikonicznego przywołania gatunku stanowi Saga Barbary Czałczyńskiej (1976). Tytułowe określenie gatunkowe pochodzi tym razem z genologii popularnej, nie naukowej (gdzie nazwa ta odnosi się do średniowiecznej formy islandzkiej) i oznacza epicką opowieść o dziejach rodziny. O trafności odniesienia świadczy koncentracja narracji na więzi, rodzinnej tradycji przekazywanej przez kolejne pokolenia: od prababki aż po matkę narratorki, a także wspomnieniowy charakter tekstu. 


\section{Sens (w) miniatur(ach)}

Miniaturyzacja wielkich form narracyjnych nie jest jednak zabawą w szarady czy podchody, których celem jest tylko odnalezienie archetekstu. Nawiązania gatunkowe pełnią bowiem w przywoływanych utworach zazwyczaj doniosłe funkcje semantyczne, przede wszystkim dlatego, że wchodzą ze wskazywanymi formami w twórczy dialog. Adaptacyjno-rozszerzający stosunek do wzorców gatunkowych jest najpopularniejszy. Podstawowemu zabiegowi służącemu adaptacji (czyli tutaj miniaturyzacji) towarzyszy zazwyczaj instrumentacja gatunkowa. Mamy więc do czynienia $\mathrm{z}$ utworami odwołującymi się do struktur gatunków na różnych poziomach i w różnych momentach. Dobrym przykładem tego zjawiska jest $Z$ pamiętnika Piotrusia Mrożka. Przedstawiona w formie fragmentu dziennika opowieść o wyprawie $\mathrm{z}$ ojcem do lasu po choinkę motywowana obawą przed kornikami, którymi specjalnie zarażone mają być drzewka $\mathrm{w}$ handlu detalicznym, kończy się wyimkiem z listu matki chłopca, nie włączonego już w obręb dziennika. Wynika z niego, że ojciec żyje w lesie z lęku przed atakiem korników zamieszkujących zakupioną w końcu choinkę. Tekst ten można jednak odczytać parabolicznie jako opowieść o paranoicznych podejrzeniach, urojonych teoriach spiskowych początku lat pięćdziesiątych (wtedy toczy się akcja), które powodują jednak całkowicie rzeczywiste reakcje lękowe. Przy takim odczytaniu oprócz nawiązania do dziennika i listu pojawiałaby się (opcjonalna, bo zależna od interpretacji) dominanta gatunkowa w postaci przypowieści, która spajałaby cały tekst i przywoływane struktury gatunkowe. Dziennik i list pełniłyby więc rolę kostiumu dla paraboli. Nowe zastosowanie zminiaturyzowanych form podkreśla produktywność przywoływanych wzorców.

Nieliczne są przykłady tekstów, w których aluzja stanowi centrum semantyczne utworu, a jej celem jest jedynie krytyka wzorca, jego parodyjne i ludyczne obśmianie - jak to się dzieje np. u Fijasa, Sterna czy w Sentencjach $i$ złotych myślach Mrożka. (Komizm pojawia się jednak często, zwłaszcza w przypadku ikonicznych znaków wielkich gatunków: zagęszczenie cech wzorca postrzegane jako wyolbrzymienie jego cech charakterystycznych obnaża jego słabość.) I w tym modelu pojawiają się jednak przypadki interesujące, bardziej złożone, jak miniaturowy metatekst o sztuce powieściowej, czyli Powieść $z$ życia wyższych sfer Głowińskiego (1998). Wymienieni w utworze przyjaciele hrabiny to bohaterowie powieści historycznych (de Bragelone, hrabina Cosel) i współczesnych (Michorowski, księżna de Sanseverin); powieści psychologicznych, społecznych, przygodowych i romansów - łączy ich jedynie arystokratyzm i przynależność do minionego świata. To oczywiście intertekstualna gra, w której możemy upatrywać pewnego elitaryzmu (wymaga bowiem kul- 
tury literackiej), wziętego jednak w cudzysłów, ponieważ wszystkie aluzyjnie wskazywane teksty należą albo do literatury popularnej (Trędowata, trylogia Aleksandra Dumasa), albo do kanonu literatury europejskiej (Ojciec Goriot, Pustelnia parmeńska). Całości patronuje zdanie, stanowiące początek utworu, a przypisywane przez Bretona Valéry'emu: „Markiza wyszła o piątej”, zdanie niemożliwe tak, jak niemożliwa miała być już powieść realistyczna. Głowiński rozpoczyna w ten sposób swój tekst, by pokazać, że jest to bezcelowe, wtórne, prowadzi do historycznych już postaci powieści, które można restytuować tylko z ironicznym dystansem - widocznym w miniaturyzacji przywoływanej formy i jej niedokończeniu.

Bardzo interesującym krytyczno-polemicznym i zarazem ludycznym nawiązaniem do archetekstu jest Poczatek powieści pisanej przez kobietę Sterna (1970). Parodii podlega tutaj nie odmiana powieściowa wyodrębniona ze względu na temat, a literatura pisana przez kobiety w ogóle. Współautor Noża $w$ brzuchu, kreując fragment takiej prozy, dokonuje zarazem bezlitosnej krytyki - utwór przypisany autorce pełen jest błędów stylistycznych (liczne nieuzasadnione powtórzenia: „Długo siedziałam sam na sam ze sobą, patrząc tępo przed siebie”, s. 114), zleksykalizowanych metafor ( $z y$ parzyly powieki, przebić wzrokiem). Przedstawiona „kobieca perspektywa" w literaturze ograniczałaby się według Sterna do tematyki rodzinno-romansowej, ukształtowanej przez narrację pierwszoosobową, dążącą do zniesienia dystansu pomiędzy narratorką a czytelnikiem/czytelniczką (choć zapewne Stern uznałby, że chodzi wyłącznie o tę ostatnią) poprzez zwroty do odbiorcy/odbiorczyni („Wy nie wiecie, co się dzieje w sercu kobiety, które kocha...”, s. 114) i zdania o charakterze wyznań („Tak, jestem przesądna i wcale się tego nie wstydzę”, s. 114).

Co równie znamienne dla tej parodii, to pasożytowanie na konwencji i zarazem nieumiejętność jej stosowania - psychologizm powieści pisanej przez kobietę sprowadza się do prostego monologu wewnętrznego, pełnego wykrzyknień i anakolutów, a wiwisekcja okazuje się jedynie opowieścią o błahych wydarzeniach i ekspresją najbardziej powierzchownych odczuć. Proza pisana przez kobietę byłaby więc literaturą o kobietach i dla kobiet, a do tego pretensjonalną, płytką i daleką od rzemieślniczej poprawności, nie mówiąc już o prawdziwym artyzmie. Cytowane już zakończenie utworu, oparte na kontraście pomiędzy fingowaną prozą kobiecą a wielką tradycją uosabianą przez Dantego, obnażać ma według Sterna nieuzasadniony charakter ambicji pisarek. Domowego piekła (jak sugeruje ten fragment - nieprawdziwego) nie można porównać do tego historycznego i zarazem metafizycznego z poematu florentczyka. Uniwersalna (pomimo kluczy personalnych i politycznych) wymowa Piekła także obnaża partykularność, subiektywność perspektywy oraz prywatny charakter rzeczywistości opisywanej przez hipotetyczną autorkę. Krytyka 
Sterna obejmująca więc styl, narrację, tematykę prozy pisanej przez kobiety ujawnia $\mathrm{w}$ istocie mizoginiczne przekonania poety na temat literatury tworzonej przez kobiety, a jego utwór stanowi fabularną kontynuację krytyki prozy kobiecej z dwudziestolecia międzywojennego, o której pisała Ewa Kraskowska ${ }^{49}$. Stern jest jednak bardziej sceptyczny niż ówcześni literaturoznawcy, którzy nie całą literaturę pisaną przez autorki rozpoznawali jako kobiecą - i z tego powodu deprecjonowali. Część pisarek przyjęła męską perspektywę i dzięki temu wyzbyła się czułostkowości, uproszczeń, egoizmu, chaotyczności i zbytniej emocjonalności, a także przestała koncentrować się na erotyce ${ }^{50}$. Stern podchodzi do relacji płci i powieści zdecydowanie bardziej deterministycznie: jeśli pisze kobieta, musi pisać źle i głupio.

W omawianym modelu nawiązań, które pełnią funkcje parodyjne i ludyczne pojawiają się jednak przypadki bardziej złożone, jak Wyspa skarbów (1990-1993) Mrożka, która pod kostiumem powieści przygodowej skrywa parabolę, z tym że oba gatunki przedstawione są jako antywzorce - formy sztuczne, kłamliwe. Na taką interpretację wymienionych gatunków wskazują przekształcenia typowych dla nich zakończeń: historia o poszukiwaniu skarbu kończy się widokiem skrzyni z krótkim acz treściwym listem, w którym autor mapy prowadzącej do zakopanego kufra napisał: „Pocałujcie mnie w dupę. Morgan” [III, s. 298]. Takie rozwiązanie fabularne uświadamia, że budowanie napięcia wokół poszukiwania skarbu, którego finał wiadomy jest dla czytelnika od momentu rozpoznania konwencji gatunkowej jest ułudą, samooszukiwaniem się, a zarazem, że prawdziwe zaskoczenie budzi rozczarowanie. Tym samym Mrożek obnaża i obśmiewa dwie konstytutywne cechy literatury popularnej rozpoznane przez Johna Caweltiego: schematyzm oraz symbolikę niebezpieczeństwa, zagrożenia, ryzyka, które pozwalają zaspokoić potrzebę bezpieczeństwa i przezwyciężyć nudę codziennego życia ${ }^{51}$. Przygoda okazuje się u Mrożka żartem, ład narracyjny zostaje obalony, a oksymoroniczna formuła literatury popularnej prowadzi tylko do rozczarowania.

Ten nieudany (bo niezgodny z konwencją gatunkową) finał prowokuje do zmiany dominanty gatunkowej - pojawia się sugestia przyjęcia alegorycznego stylu odbioru ( $w$ terminologii Głowińskiego ${ }^{52}$ ) i próba prze-

49 E. Kraskowska, Piórem niewieścim. Z problemów prozy kobiecej dwudziestolecia międzywojennego, wyd. II przejrzane i zmienione, Wyd. Naukowe UAM, Poznań 2003, s. $13-36$.

50 Tamże, s. 16-23.

51 J.G. Cawelti, Formuly, gatunki i archetypy, przeł. A. Fulińska, „Znak” 1996, nr 10.

52 Zob. M. Głowiński, Świadectwa i style odbioru, [w:] tegoż, Style odbioru: szkice o komunikacji literackiej, Wyd. Literackie, Kraków 1972. 
transponowania przedstawionej fabuły $\mathrm{w}$ parabolę53. Gucio stwierdza: „Cel nigdy nie jest ważny. Tylko wysiłek w dążeniu do celu się liczy, a nie osiągnięcie celu” [III, s. 298]. Poszukiwanie skarbu, którego nie ma jako metafora drogi życia? Możliwe, ale nie tym razem. Schemat przypowieści zostaje bowiem także przełamany: „Zabiłem Gucia i wróciłem do domu. Lubię pouczające sentencje, ale bez przesady" [III, s. 298]. Im bardziej więc początek utworu rozbudzał oczekiwania czytelnika związane z rozwojem akcji zgodnym ze schematem fabularnym gatunku, tym mocniej zakończenie mu zaprzecza, co znajduje potwierdzenie $\mathrm{w}$ konstatacjach Anny Martuszewskiej na temat gier literackich ${ }^{54}$, z którymi w tym przypadku mamy do czynienia.

Skostniała, schematyczna okazuje się więc nie tylko powieść przygodowa (co nie dziwi ze względu na formułowość literatury popularnej w ogóle), ale także parabola, oferująca te same morały w wielu sytuacjach. Mrożka prowokuje w nich, wydaje się, jednak nie tylko przewidywalna fabuła, ale przede wszystkim łatwy dydaktyzm. Oba gatunki posługują się prostymi, czarno-białymi klasyfikacjami, a ich przesłania moralne $\mathrm{w}$ tradycyjnych realizacjach obu gatunków należą do truizmów, prawd potocznych: nagroda dla herosów, którzy pokonali/przechytrzyli złoczyńcę to podstawowy schemat literatury popularnej ${ }^{55}$, a zaskakująca, mądrościowa puenta zmieniająca interpretację przedstawionej sytuacji to element przypowieści biblijnych. Mrożek sugeruje jednak, że herosi popularni to tacy sami zbrodniarze, jak ich oponenci, jedynie happy end w myśl sentencji Gogola „Szczęśliwym zwycięzcom historia zawsze wybacza”, zmienia postrzeganie ich roli. Próbę przerobienia rozczarowania, frustracji w objawienie istoty bytu Mrożek demaskuje jako zwykłe szalbierstwo. Równocześnie twierdzi, że tylko takie antypowieści przygodowe i kontrprzypowieści zawierają prawdziwe zwroty akcji - zaskakujące, bo wykraczające poza schematy fabularne gatunków, a przez to atrakcyjne dla czytelnika. Zamiast jednak dawać zadowolenie i poczucie bezpieczeństwa wprowadzają w świat nieoczywistości, tym silniej przeciwstawiając się formułowej literaturze, która „stanowi odbicie konstrukcji świata idealnego, pozbawionego nieporządku, dwuznaczności, niepewności i ograniczeń świata naszych doświadczeń"56.

53 Agnieszka Fulińska uważa takie mariaże za częste, zob. A. Fulińska, Dlaczego literatura popularna jest popularna?, „Teksty Drugie” 2003, nr 4, s. 62.

54 Por. A. Martuszewska, Radosne gry. O grach/zabawach literackich, słowo/obraz terytoria, Gdańsk 2007, s. 178.

$55 \mathrm{Na}$ temat dydaktyzmu literatury popularnej zob. A. Martuszewska, „Ta trzecia”..., dz. cyt., s. 22-25.

56 J.G. Cawelti, Formuty..., dz. cyt., s. 125. 
Epos Parnickiego (1958), Saga Czałczyńskiej (1976) [czy Życie wspótczesne Mrożka (1957)] prezentują z kolei transgresyjny model nawiązania do gatunku. Widać to bardzo dobrze w tym pierwszym, opisanym już wcześniej szerzej przypadku. Eliminacja elementów nadprzyrodzonych, kontekstu społecznego i kulturowego, dowartościowanie prywatnej sfery życia, a także porzucenie narracyjnej perspektywy olimpijskiej i zawężenie fokalizacji do świadomości jednego bohatera wraz $\mathrm{z}$ techniką strumienia świadomości pozwala udowodnić tezę zawartą w motcie zaczerpniętym z pism Tomasza Manna: „Ludzie są zawsze ludźmi; we wszystkich epokach myśleli i czuli tak samo jak my...”. Tekst Parnickiego stanowi swoisty eksperyment na małej próbie (jednym epizodzie) współczesnego eposu - otrzymujemy wersję gatunku nie tylko uczłowieczoną, ale także prezentującą perspektywę jednostkową, prywatną. Tym samym tekst, nazwany eposem bliższy jest jednak miniaturze powieści, która ukazać ma właśnie „prawdę żywego człowieka”57.

Saga Czałczyńskiej stanowi przypadek odmienny. Więcej jest bowiem w tym tekście punktów stycznych z przywoływaną w tytule formą, równocześnie jednak gwałtowniej przekracza on jej ramy. Pisarka wprowadza kobiecą perspektywę i doświadczenie poprzez bohaterkę-narratorkę, a jak zauważa Inga Iwasiów: „Większość sag, tak jak całość kultury opiera się na męskim narratorze"58. Kompulsywnie powtarzana przez Czałczyńską fraza „kobiety w mojej rodzinie” prowadzi jedynie do stwierdzenia, że „Kobiety w mojej rodzinie zawsze zostawały same” [s. 13] ${ }^{59}$, zamiast bliskości, sukcesji charakterystycznych dla sagi - alienacja, której żadne więzy z dziećmi nie są w stanie przezwyciężyć. Winny temu jest patriarchalizm i androcentryzm kultury; dla kobiet z rodziny narratorki centrum egzystencji stanowili mężczyźni: mężowie i synowie (zgodnie $\mathrm{z}$ prawem patrylinearnym ojcowie nie pojawiają się $\mathrm{w}$ tym tekście ani razu, kobieta, wychodząc za mąż, porzuca i nazwisko, i dotychczasową rodzinę). Ci jednak, jako należący przede wszystkim do sfery publicznej, a nie rodzinnej czy prywatnej, naznaczeni byli śmiercią, ponieważ ich podstawowym obowiązkiem jest służba ojczyźnie. W tej wizji kultury kobieta ograniczona do roli matki i przywiązana do ogniska domowego równocześnie jednak jest ograbiana $\mathrm{z}$ tego jedynego dobra - rodziny - w imię nadrzędnego, wspólnego. Czałczyńska zdaje się więc twierdzić, że samo

57 Por. S. Skwarczyńska, Epos a powieść..., dz. cyt., s. 166; zob. także M. Bachtin, Epos $i$ powieść..., dz. cyt., s. 552-578 oraz P. Bohuszewicz, Pomiędzy eposem a powieścia, „Acta Universitatis Nicolai Coperncii, Filologia Polska” 2006, LXIII, s. 5-11.

58 I. Iwasiów, Gender dla średnio zaawansowanych: wykłady szczecińskie, W.A.B., Warszawa 2004, s. 138.

59 B. Czałczyńska, Wielka cisza, Kraków 1976. Wszystkie cytaty na podstawie tego wydania, numer strony podaję w nawiasie za cytatem. 
uczynienie kobiety narratorką sagi prowadzi do aporii: w relacjach rodzinnych doświadcza ona tylko straty, przeżywa bezustanną od chwili zamążpójścia żałobę.

Eksperyment, jaki na tym gatunku przeprowadza pisarka, idzie jednak zdecydowanie dalej. Macierzyństwo oparte na tym, że ma się dzieci, nie precyzuje przecież ich płci, cóż więc dzieje się z córkami? Dlaczego ich obecność nie prowadzi do przełamania samotności? Można przecież wyobrazić sobie matriarchalną czy feministyczną wspólnotę (umożliwiającą sagę), opartą na dziedziczeniu po kądzieli chociażby w sferze emocjonalnej czy wyobrażeniowej. Czałczyńska nie pisze o tym wprost, jednak cała Saga prowadzi do wniosku, że to niemożliwe, kobiety bowiem są raz na zawsze rozdzielone przez śmierć; cały świat matki to dzieci - ale tylko synowie, córki przecież odchodzą - wychodzą za mąż: „wiedziałam, że dla mojej matki jedyną ważną rzeczą w życiu jest być dobrą żoną i matką. Nikogo nie interesowało, czym się zajmuję. Tak więc bez wiedzy i woli matki skończyłam szkołę, zapisałam się na studia i zaczęłam pracować" [s. 15]. Kobiety łączy jedynie przepaść, jaka otwiera się między nimi. Córka, wchodząc do pokoju matki schludnością świadczącego o samotności, „nie przekracza nigdy progu codzienności” bo, jak wyznaje „nie możemy sobie zakomunikować czegokolwiek z przeszłości, co byłoby nam nieznane. Obie znamy równie dobrze całe życie jej synów, moich braci..." [s. 15]. Są oni naznaczeni przez śmierć - cóż więc może znaczyć wobec nich zwykła (bo żywa) córka i jej (prywatne) sprawy? Ale także kobieta, która innemu mężczyźnie urodzi kolejnego syna. Kobieta, która sama sobą nic nie znaczy, może być tylko łączniczką pomiędzy pokoleniami martwych mężczyzn. W tej optyce (prezentowanej przez matkę protagonistki) kobieta to rzeczywiście ziejąca grozą pustka.

Narratorka stwierdziła na koniec: „Wydaje mi się jednak, że jest poza tym wszystkim coś, co nas łączy. Bo my obie, moja matka i ja, każda na swój sposób robimy stale jeden i ten sam wysiłek. Żeby o tym, co było poza nami, zapomnieć" [s. 16]. Szansą na więź (a więc i na sagę) byłoby wymazanie $\mathrm{z}$ tego rodzinnego równania nieżyjących; opowieść o tych, które wciąż żyją, ale nigdy nie miały niezależnej od mężczyzn (synów, mężów, braci) wartości - i własnej opowieści. Narratorka w swojej historii rodzinnej przedstawia się więc jako córka i jako matka: uznaje ciągłość kobiecej tożsamości, niezależnej od związków z mężczyznami (ojcem i mężem), w tym sensie jest to $\mathrm{z}$ pewnością próba zrozumienia własnej współczesności60. Opisywana relacja (bo nie więź) z matką ukazuje problematyczność dziedzictwa w linii żeńskiej, ale także (nawet w tej negatywnej formie) zapewnia genealogię. Wybór matronki, a nie patrona

${ }^{60}$ I. Iwasiów, Gender..., dz. cyt., s. 140. 
dla własnej historii wydaje się tutaj znaczący: ojciec jest nieobecny w wychowaniu dzieci, zwłaszcza córek, niekoniecznie przez śmierć, ale przede wszystkim ze względu na patriarchalny model rodziny, który wyklucza go z tej sfery życia. Z matką łączą też narratorkę całkowicie cielesne więzy - okres ciąży.

Czałczyńska rozwija także sagę zstępująco: przedstawia się jako matka syna, który jednak został przeciągnięty na stronę dotychczas kobieca - na stronę żywych. I wydaje się, że to zawłaszczenie go i udomowienie (odebranie go ojczyźnie i uczynienie trwałym elementem rodziny, a więc i życia kobiety) buduje płaszczyznę konfrontacji, a zarazem dialog między matką i córką:

Kiedy mój syn skończył szkołę i zapisał się na studia, moja matka powiedziała z lekkim wahaniem w głosie:

- Będzie żył.

Odpowiedziałam spokojnie:

- Będzie żył.

Kiedy mój syn skończył studia, moja matka spytała:

- Pewno się teraz ożeni?

- Ma czas - odpowiedziałam.

- Ma czas - powtórzyła moja matka ze zdziwieniem.

Mężczyźni w naszej rodzinie nigdy nie mieli czasu. Żenili się, jak tylko mogli najszybciej, żeby zachować ciągłość życia w rodzinie, a o ich istnieniu świadczyły wdowy i sieroty, które pozostawiali po sobie [s. 14-15].

Patriarchalna kultura zapewnia sukcesję - i umożliwia sagę - tylko w linii męskiej, kolejnych bohaterów wprowadzają martwi przodkowie; dla kobiecej sagi, przeciwnie, fundamentem jest pragnienie życia i trwanie przypisane esencjalistycznie do kobiecości61. Utwór Czałczyńskiej dobitnie świadczy o tym, że taka saga stanowi jedynie postulat, bo kobieca próba opowieści o rodzinie, tradycji, bliskości prowadzi do wyznania samotności matek i córek: „Zaczynam myśleć, że my z matką jesteśmy prawie całkiem obcymi sobie kobietami” [s. 16]. Kobieca saga (ważna forma dla feministycznych i popfeministycznych projektów genealogicznych ${ }^{62}$ ) jest niemożliwa $\mathrm{z}$ powodu patriarchalizmu polskiej kultury: brzuch matki zamiast myśli o dawnym ciało-w-ciało budzi uczucie alienacji, pępowina została przecięta ${ }^{63}$. Martwi mężowie, synowie, bracia niszczą tę więź, zanim zdąży się ona pojawić. Saga pokazuje więc, że próba modyfikacji wzorca gatunkowego przez uczynienie kobiety narratorką

61 Por. tamże.

62 Zob. tamże, s. 138.

${ }^{63}$ Zob. L. Irigaray, Ciało $w$ ciało $z$ matka, przeł. A. Araszkiewicz, Wyd. eFKa, Kraków 2000. 
prowadzi do obnażenia społeczno-kulturowych uwarunkowań tej formy: patriarchalizmu i etosu narodowego, które tak silnie dominują w wyobraźni odbiorców, że stają się oczywiste i niezauważalne. Zrodzona z tej świadomość krytyka samej formy - przedstawienia historii kobiety („herstory") prowadzi jednak do ukazania jej niemożliwości. Zadany tytułem, niczym ćwiczenie z poetyki, gatunek sagi prowadzi do jej zaprzeczenia i skonstruowania wyznania samotności egzystencjalnej i społecznej.

\section{Mniej znaczy równie dużo}

Nawiązania do wielkich form narracyjnych w małych prozach są zjawiskiem różnorodnym i wielopoziomowym, a kluczową rolę odgrywa w nich tytuł, który niejako w opozycji do dwudziestowiecznych tendencji, zauważalnych także wśród małych form narracyjnych, zawiera określenie gatunkowe ${ }^{64}$. Pełni doniosłą rolę, ponieważ z jednej strony kształtuje horyzont oczekiwań czytelniczych (które sam tekst zawodzi) - jest więc doniosłym elementem komunikacji literackiej, z drugiej natomiast umiejscawia utwór w genologicznej przestrzeni hermeneutycznej, sprawiając, że nie tylko konstrukcja tekstu znajduje uzasadnienie na tle tradycji, ale i on sam skonfrontowany $z$ wyposażeniem aksjologicznym i semantycznym przywoływanego gatunku przestaje jawić się jako parodia o cechach ludycznych lub nieudana realizacja np. powieści. Tytuł $\mathrm{w}$ przypadku omawianych małych form narracyjnych odgrywać może więc kluczową rolę: stanowi metatekst sterujący interpretacją ${ }^{65}$. Bez niego wiele $\mathrm{z}$ omawianych aluzji byłoby słabo widocznych, a czasami nieczytelnych; tytuł zawiera także informacje, pozwalające wnioskować o sposobach i funkcjach przywoływania wielkich form narracyjnych.

Spostrzeżenie Michałowskiego odnośnie do roli gatunkowych określeń w tytule potwierdza się w prozie jednak tylko częściowo - nie jest ono warunkiem sine qua non zauważalnej miniaturyzacji, czy, jakby powiedział badacz, skrótu66. Zdarza się, że elementem wskazującym na obszerny archetekst małej formy oraz na relację pomiędzy nimi jest także rama tekstu zdradzająca intencje nadawcy w kreowaniu aluzji do wielkich form narracyjnych. Dzieje się tak nie tylko w przypadku omawianego Życia współczesnego Mrożka, ale także w Życiu i myślach (1980-1989) oraz w Opowieści starego agenta (1980-1989) tegoż autora, stanowiącej

64 Por. D. Danek, Dzieło literackie jako książka. O tytułach i spisach rzeczy w powieści, PWN, Warszawa 1980, s. 104.

65 To jedna z dwóch funkcji (obok oznaczającej) wymienianych przez Danek, zob. tamże, s. 77,82 .

66 P. Michałowski, Miniatura poetycka, dz. cyt., s. 186-187. 
indeksalne nawiązanie do powieści sensacyjnej. Śledzimy bowiem spotkanie dwóch agentów w kawiarni prowadzące do nawiązania kontaktu operacyjnego z przedstawicielem obcego wywiadu. Informacje ujawnione czytelnikowi (znaki rozpoznawcze, techniki maskujące, jak również dysonans pomiędzy przedstawioną sytuacją i jej interpretacją przez protagonistów) wskazują na parodyjność tego nawiązania, ale także pozwalają czytelniczce (przez popularność społeczno-politycznych paraboli w pisarstwie Mrożka) domyślać się $\mathrm{w}$ przedstawionej sytuacji groteskowego obrazu państwa i jego aparatu władzy, który wszędzie dopatruje się wrogów. Rama tekstu - ujawniona dopiero w ostatnich akapitach musi jednak prowadzić do rekapitulacji tych hipotez interpretacyjnych. Zakończenie dostarcza nowych informacji dotyczących pomijanej sfery sytuacji wypowiadania. Przywołanie powieści szpiegowskiej okazuje się mistyfikacją, gdyż narrator przedstawiający się jako agent wywiadu demaskuje się jako alkoholik, który próbuje wyłudzić od innych gości lokalu pół litra „na małpę” - opowiadając przedstawioną wcześniej historię przesłuchań agenta wrogiego państwa, ukrywającego się w kostiumie zwierzęcia. Za sprawą manipulacji informacjami Mrożek konstruuje więc tekst, który początkowo wydaje się parodią powieści szpiegowskiej prawdopodobnie o podtekście społeczno-politycznym, by okazać się ostatecznie opowiadaniem o kompozycji ramowej, w którym nawiązanie do schematu fabularnego powieści szpiegowskiej odbywa się na poziomie świata przedstawionego całkowicie serio, a parodyjny charakter jest efektem niezamierzonym (w obrębie świata przedstawionego), wynikającym najprawdopodobniej z niedostatecznej sprawności narracyjnej i próby dostosowania gatunku do celów utylitarnych. Gra z odbiorcą, charakterystyczna dla powieści szpiegowskiej, odbywa się więc na wyższym poziomie niż zazwyczaj - odbiorca ma rozpoznać nie tyle czy małpa to rzeczywiście agent, ile - co motywuje tak absurdalną dla tej odmiany fabułę, czyli $\mathrm{z}$ jakim gatunkiem mamy do czynienia ${ }^{67}$.

Nie tylko tytuł i rama tekstu, ale także konstrukcja świata przedstawionego, schematy narracyjne, segmentacja tekstu stanowią, tak jak i w przypadku nawiązań małych form narracyjnych do niewielkich objętościowo gatunków, ważne czynniki wskazujące na adres architekstualnych nawiązań i ich funkcje.

Michałowski o skrótach poetyckich pisał:

Trudno znaleźć miniaturę, do końca będącą „korektą zwięzłości” innego tekstu lub gatunku. Brakuje zatem konstruktywnej polemiki metapoetyckiej, gdzie

$67 \mathrm{Na}$ temat gier związanych z sytuacją nadawczo-odbiorczą i opartych na manipulacji informacjami w powieści kryminalnej por. A. Martuszewska, Radosne gry..., dz. cyt., s. 82-83. 
forma krótsza konkurowałaby z dłuższą; takiej co wykraczałaby całkowicie poza żart, postulując zmodyfikowaną postać wypowiedzi już istniejącej - w postaci tekstu albo pustej struktury. Zarówno arcydzieła, jak i gatunki wychodzą z tych prób rywalizacji niepokonane ${ }^{68}$.

Wydaje się, że narracyjne miniatury wielkich form, przeciwnie, stanowią może nie konkurencję, ale alternatywę dla swych archetekstów: ujawniają nie tylko ich schematyzm (Cena sławy), ale także uwarunkowania i ograniczenia kulturowe (Saga, Uwagi historyczne), podejmują dyskusję na temat różnych modeli literatury (Wyspa skarbów, Powieść $z \dot{z} y c i a$ wyższych sfer); oprócz problematyki metatekstowej poruszają także zagadnienia z zakresu antropologii (Epos), służą krytyce rzeczywistości społecznej (Życie wspótczesne, $Z$ pamiętnika Piotrusia) i ekonomicznej ( $Z$ notatnika kapitalisty), do wyjątków można w zasadzie zaliczyć utwory, których dominującą i w zasadzie jedyną funkcją jest funkcja ludyczna i wyśmianie przywoływanego gatunku (Makaron, piraci, hajże na ribeire!, Opowieść starego agenta, Poczatek powieści pisanej przez kobietę). Niczym średniowieczne miniatury stanowią twórczość na marginesie, ale pełnowartościową, pełną różnorodnych form, środków wyrazu i bogactwa znaczeń.

68 Tamże, s. 191. 